J. Dairy Sci. 96:3547-3550

http://dx.doi.org/10.3168/jds.2012-6225

(C) American Dairy Science Association ${ }^{\circledR}, 2013$. Open access under CC BY-NC-ND license.

\title{
Short communication: Jenny milk as an inhibitor of late blowing in cheese: A preliminary report
}

\author{
C. Cosentino, ${ }^{1}$ R. Paolino, P. Freschi, and A. M. Calluso \\ School of Agricultural, Forest, Food, and Environmental Sciences, University of Basilicata, Viale dell'Ateneo Lucano 10, Potenza 85100, Italy
}

\section{ABSTRACT}

Late blowing on semihard and hard cheese may have an important economic effect on dairy production. Many studies have attempted to prevent this defect by physical treatment, the use of additives, and the use of bacteriocins. In this paper, we look at the effect of jenny milk as an inhibitor of blowing caused by clostridia and coliforms in ewe cheese making. Bulk ewe and jenny milk samples were collected in the morning by mechanical milking and were refrigerated at $4^{\circ} \mathrm{C}$. On the collected samples, the count of somatic cells, coliforms, Clostridium butyricum, and Escherichia coli were determined. The bulk raw milk was divided in two 45-L vats: vat 1 was used as a control, whereas $0.5 \mathrm{~L}$ of jenny milk was added to vat 2 . Four semihard cheeses, weighing about $2 \mathrm{~kg}$ each, were made from each vat. Cheese making was replicated twice. After a ripening period of $60 \mathrm{~d}$, the count of coliforms and of C. butyricum was determined. In the treated group, a significant inhibition of coliform bacteria was observed. The addition of jenny milk in cheese making may prove to be a useful and innovative approach for the inhibition of spore-forming clostridia strains.

Key words: jenny milk, lysozyme, cheese making, late blowing

\section{Short Communication}

Jenny milk displays good tolerability, as well as high nutritional and functional properties. These characteristics are due to its protein profile, high lactose content, and peculiar FA composition. Moreover, its whey protein fraction is higher than that of cow's milk: $\alpha$-lactalbumin and $\beta$-lactoglobulin range from 35 to $50 \%$ of the total nitrogen fraction in jenny milk (Herrouin et al., 2000; Guo et al., 2007). Jenny milk is characterized by a high lysozyme content; lysozyme is a well-known natural antimicrobial agent that may contribute to the inhibition of bacterial growth (Chiavari et al., 2005; Polidori and Vincenzetti, 2007; Cosentino

Received October 3, 2012.

Accepted March 1, 2013.

${ }^{1}$ Corresponding author: carlo.cosentino@unibas.it et al., 2012a,b). Additionally, jenny milk provides an array of defense protein factors, such as lactoperoxidase, lactoferrin, lysozyme, and immunoglobulin, all with the capability to kill or to inhibit a large spectrum of pathogens (Zhang et al., 2008; La Torre et al., 2010; Nazzaro et al., 2010). Lysozyme antibacterial activity is due to its capacity to catalyze the hydrolysis of the $\beta$ 1-4 glycosidic links between $N$-acetylmuramic acid and $\mathrm{N}$-acetylglucosamine in the bacterial cell wall of polysaccharides, working in synergy with lactoferrin and immunoglobulins.

The main external source of microbial contamination in milk has been identified in poorly stored silage with bacterial spores that can withstand the pasteurization process (Vissers et al., 2006, 2007a). The anaerobic lactate-fermenting clostridia in cheese (Clostridium tyrobutyricum and Clostridium butyricum) can reach more than $110 \mathrm{cfu} / \mathrm{g}$ within 4 to $6 \mathrm{wk}$, producing late blowing characterized by excessive gas and off-flavor production (Hughey and Johnson, 1987; Senyk et al., 1989; Kalač, 2011). Growth of C. butyricum in cheese is critically affected by different factors, such as salt concentration, $\mathrm{pH}$, ripening time, and temperature, as well as by the presence of other microorganisms (Garde et al., 2011). Previous studies have attempted to prevent late blowing by means of physical treatments, such as bactofugation or microfiltration before processing, or by the use of additives such as nitrate or lysozyme (Wasserfall and Teuber, 1979; Vissers et al., 2007b; Schneider et al., 2010a). In recent studies, the addition of lactic acid bacteria-producing bacteriocins to strains during cheese manufacture was evaluated as an alternative strategy to prevent this defect. These biologically active peptides display a bactericidal mode of action toward specific gram-positive bacteria (Martìnez-Cuesta et al., 2010). Among several methods of prevention, lysozyme, as a commercial additive, has been preferred since 1983; it is extracted from hen egg white (HEW; $3.5 \%$ of the egg white proteins). Presently, the application of this preservative (E1105) is legal in the entire European Community, according to European Parliament Directive No. 95/2/EC (quantum satis in ripened cheese) (Pellegrino and Tirelli, 2000; Scharfen et al., 2007; Schneider et al., 2011). However, lysozyme HEW is becoming less attractive as a preven- 
tion agent, as some studies have shown its allergenic effect in consumers allergic to egg, due to its content in ovomucoid, ovoalbumin, and conalbumin (Frémont et al., 1997; Pérez-Calderón et al., 2007).

In the last decade, several case studies revealed severe allergic reactions due to the presence of lysozyme E1105 in semihard cheeses. Frémont et al. (1997) noted that $35 \%$ of patients allergic to eggs had antilysozyme $\mathrm{IgE}$, and a few of them previously experienced a severe reaction after eating Gruyere cheese. In Sweden, it was reported that 5 out of 21 case studies of allergic reactions to eggs were attributed to the presence of this additive in cheese (Kerkaert et al., 2010). In addition, Pérez-Calderón et al. (2007) demonstrated that this additive is likely responsible for episodes of severe edema. In fact, as indicated in recently changed European Commission legislation, the use of lysozyme as an additive has to be declared on the label (EC legislation in Europe 2003/89/ EC, Directive 2000/13/EC). It is necessary, therefore, to reliably detect and quantify this preservative in cheese (Iaconelli et al., 2008; Kerkaert et al., 2010; Dragoni et al., 2011).

In Italy, the use of lysozyme is widespread (Panari and Filippi, 2009); lysozyme has been detected in Grana Padano, in grated hard cheese mixtures (Cocolin et al., 2004; Iaconelli et al., 2008), and in semihard goat and ewe cheeses (Dragoni et al., 2011; Schneider et al., 2010b, 2011). Even though the current commercial source for lysozyme is from HEW, it is present also in milk, blood serum, tears, and saliva (Callewaert and Michiels, 2010). Some authors observed that lysozyme from mare, jenny, and cow milk does not derive from potentially allergenic sources and could be used as a substitute of HEW lysozyme (Cosentino and Paolino, 2012; Galassi et al., 2012). Donkey lysozyme is of the c-type, which is 129 AA long and exhibits $50 \%$ homology to the human protein. The lysozyme content in jenny milk ranges between 1.0 and $3.7 \mathrm{mg} / \mathrm{mL}$, according to the lactation stage and the production season (Chiavari et al., 2005; Zhang et al., 2008; Galassi et al., 2012; Vincenzetti et al., 2012), and it is much higher than in cow $(0.13 \mu \mathrm{g} / \mathrm{mL})$, ewe $(0.20 \mu \mathrm{g} / \mathrm{mL})$, or goat milk $(0.25 \mu \mathrm{g} / \mathrm{mL}$; Fratini et al., 2006; Scharfen et al., 2007; Cosentino and Paolino, 2012). The aim of this study was to investigate the effect of lysozyme from jenny milk on blowing defects in artisanal ewe cheese caused by clostridia and coliforms, usually present in ewe cheese produced in traditional cheese factories.

\section{Milk}

Bulk ewe and jenny milk were taken on the same day from 2 semiextensive rearing farms that used mechanical milking, both situated in Basilicata at about 750
Table 1. Parameters of ewe and jenny milk

\begin{tabular}{lcc}
\hline & \multicolumn{2}{c}{ Milk } \\
\cline { 2 - 3 } Parameter & Ewe & Jenny \\
\hline Protein, \% & 6.56 & 1.62 \\
Fat, \% & 8.40 & 1.10 \\
Clostridium butyricum, cfu/mL & 10 & $<10$ \\
Coliform, cfu/mL & 166 & 170 \\
Escherichia coli, cfu/g & $<1$ & $<1$ \\
SCS, $\log _{10}$ no./mL & 5.73 & 5.18 \\
\hline
\end{tabular}

$\mathrm{m}$ above sea level. Jennies were at the second month postfoaling. After collection, milk aliquots were immediately refrigerated at $4^{\circ} \mathrm{C}$ and transported to the laboratory for analytical determinations.

On raw ewe and jenny milk we measured protein and fat content by Milkoscan FT 6000 (Foss Electric, Hillerød, Denmark) according to the International Dairy Federation standard (ISO, 2000) and SCS $\left(\log _{10} n \times\right.$ $1,000 / \mathrm{mL}$ ) according to ISO (2006a). Moreover, we enumerated C. butyricum spores according to ISO (2004), coliforms according to ISO (2006b) and Escherichia coli as described in ISO (2001). Lysozyme content in ewe and in jenny milk was determined by HPLC (1100 system, Agilent Technologies) according to Pellegrino and Tirelli (2000).

\section{Cheese}

Semihard cheeses, produced from $90 \mathrm{~L}$ of ewe milk, were manufactured and seasoned on the dairy farm. Milk was heated at $37^{\circ} \mathrm{C}$, and then $0.3 \mathrm{~g} / \mathrm{L}$ of kid rennet (activity 1:10,000; Caglio Camoscio CSC 95/75, DMS Segrate, Italy) was added. Bulk raw milk was divided into two 45-L vats: vat 1 was used as a control and 0.5 $\mathrm{L}$ of jenny milk with a lysozyme content of $0.5 \mathrm{mg} / \mathrm{L}$ was added to vat 2 . This volume of jenny milk ensures the lysozyme quantity ordinarily used in the making of some Italian cheeses (e.g., in Grana Padano cheese making it is permissible to use up to a maximum of 2.5 $\mathrm{g} / 100 \mathrm{~kg}$ of milk; Iaconelli et al., 2008; Galassi et al., 2012).

After $35 \mathrm{~min}$, the formed curds were cut, heated at $37^{\circ} \mathrm{C}$, and pressed into cylindrical molds. From the 2 vats, 4 semihard cheeses weighing about $2 \mathrm{~kg}$ each were obtained. After $24 \mathrm{~h}$ of draining, cheeses were salted in containers with sterile brine $(200 \mathrm{~g} / \mathrm{L}$ of $\mathrm{NaCl}, \mathrm{pH} 5.40)$ for $2 \mathrm{~h}$ and then stored at $20^{\circ} \mathrm{C}$ for $4 \mathrm{~d}$. Molds were then seasoned for $60 \mathrm{~d}$ in a ripening room at the temperature of $15^{\circ} \mathrm{C}$ with an air humidity of 80 to $85 \%$. Cheese making was replicated twice. During ripening, blowing defects were monitored. After the ripening period, the obtained cheeses were sampled and protein and fat 
Table 2. Variation of qualitative parameters in ewe cheeses (mean \pm SE)

\begin{tabular}{lccc}
\hline Parameter & Control & Treated & Significance \\
\hline DM, \% & $59.52 \pm 0.43$ & $60.26 \pm 0.31$ & NS \\
Protein, $\%$ & $25.63 \pm 0.20$ & $25.19 \pm 0.14$ & NS \\
Fat, \% & $26.42 \pm 0.31$ & $26.98 \pm 0.22$ & NS \\
pH at $25^{\circ} \mathrm{C}$ & $5.68 \pm 0.03$ & $5.60 \pm 0.02$ & NS \\
Lysozyme, $\mathrm{mg} / \mathrm{kg}$ & $1.97 \pm 0.19$ & $2.57 \pm 0.13$ & $*$ \\
Clostridium butyricum, $\log _{10}$ no./g & $1.65 \pm 0.20$ & $1.56 \pm 0.14$ & NS \\
Coliforms, $\log _{10}$ no. $/ \mathrm{g}$ & $4.53 \pm 0.07$ & $4.24 \pm 0.05$ & $* *$ \\
\hline$P<0.05 ; * * P<0.01$. & & &
\end{tabular}

content was measured by NIR (NIR System 5000, Foss) and $\mathrm{pH}$ (PHM 240, MeterLab, Lyon, France).

In the cheeses we detected the enumeration of $C$. butyricum spores (ISO, 2004), coliforms (ISO, 2006b), and E. coli (ISO, 2001). Lysozyme content in ewe and in jenny milk was determined by HPLC (1100 system, Agilent Technologies) according to Pellegrino and Tirelli (2000). Data were submitted to ANOVA; comparison between groups was evaluated by Student's $t$-test.

In jenny and in ewe milk we observed similar concentrations of coliforms (170 and $166 \mathrm{cfu} / \mathrm{mL}$, respectively) and $E$. coli $(<1 \mathrm{cfu} / \mathrm{g}$ in both groups). Content of $C$. butyricum was measured at $10 \mathrm{cfu} / \mathrm{mL}$ in ewe milk and $<10 \mathrm{cfu} / \mathrm{mL}$ in jenny milk. Ewe milk was composed of $6.56 \%$ protein, $8.40 \%$ fat, and an SCS of $5.73 \log _{10} \mathrm{n} /$ $\mathrm{mL}$ (Table 1). Protein and fat content were in line with the values reported by other authors on some Italian ewe breeds (Pulina et al., 2005).

\section{Results and Discussion}

Cheeses from the 2 groups presented a similar qualitative composition (Table 2). The total content of lysozyme was significantly higher $(+0.6 \mathrm{mg} / \mathrm{kg})$ in the treated cheeses compared with control $(1.97 \mathrm{mg} / \mathrm{kg})$. The lysozyme activity was evident by the inhibition of coliform bacteria in the experimental group. In fact, the enumeration of coliforms were significantly higher $(P<0.01)$ in the control $\left(4.53 \log _{10} \mathrm{cfu} / \mathrm{g}\right)$ compared with the treated cheeses $\left(4.24 \log _{10} \mathrm{cfu} / \mathrm{g}\right)$. The treatment did not significantly affect the number of clostridia spores. Only in the control did we observe late blowing. The lower content of coliforms in treated ewe cheese was in agreement with results from the literature on reduced growth of $C$. butyricum in Grana Padano (Iaconelli et al., 2008; Dragoni et al., 2011) and Gouda cheese (Bester and Lombard, 1990). Martìnez-Cuesta et al. (2010) observed a higher contamination of Clostridium in Machego control cheese compared with that treated with lysozyme HEW (spores were 8.56 vs. 1.82 $\log _{10} \mathrm{cfu} / \mathrm{g}$ ). Recently, Galassi et al. (2012) described the addition of jenny milk as a substitute for egg lyso- zyme in Grana Padano cheese to prevent late blowing. They also studied the physico-chemical and microbiological aspects of milk and cheeses; those values were significantly lower in cheese treated with jenny milk compared with those produced the traditional way.

The addition of jenny milk in cheese making may prove, therefore, to be a useful and innovative approach for the inhibition of spore-forming clostridia strains, the main cause of late blowing in cheese. Lysozyme from jenny milk is a potential alternative to egg lysozyme. The breeding of ewes in extensive rearing might include a small number of jennies able to satisfy the amount of milk required for cheese making, utilizing the same milking machine with a different pulsations variator. Further trials should be carried out to confirm the above results.

\section{ACKNOWLEDGMENTS}

This study was supported by Regione BasilicataOnocosmesis Project "Conservation and preservation of the mule species through the exploitation of marginal areas in onocosmesis products from donkey milk."

\section{REFERENCES}

Bester, B. H., and S. H. Lombard. 1990. Influence of lysozyme on selected bacteria associated with Gouda cheese. J. Food Prot. 53:306-311.

Callewaert, L., and C. W. Michiels. 2010. Lysozymes in the animal kingdom. J. Biosci. 35:127-160.

Chiavari, C., F. Coloretti, M. Nanni, E. Sorrentino, and L. Grazia. 2005. Use of donkey's milk for a fermented beverage with lactobacilli. Lait 85:481-490.

Cocolin, L., N. Innocente, M. Biasutti, and G. Comi. 2004. The late blowing in cheese: A new molecular approach based on PCR and DGGE to study the microbial ecology of the alteration process. Int. J. Food Microbiol. 90:83-91.

Cosentino, C., and R. Paolino. 2012. Il latte di asina, uno stabilizzante naturale per formaggi a pasta dura (Jenny milk, a natural additive in semi hard cheeses). Agrifoglio Rivista bimestrale ALSIA 41:32-33.

Cosentino, C., R. Paolino, P. Freschi, and A. M. Calluso. 2012a. Short communication: Jenny milk production and qualitative characteristics. J. Dairy Sci. 95:2910-2915.

Cosentino, C., R. Paolino, P. Freschi, and A. M. Calluso. 2012b. Zoom sul latte d'asina: Più ricco di lattosio e con maggiore conservabilità 
(Zoom on jenny milk: Richest in lactose and with highest shelf life). Agrifoglio Rivista bimestrale ALSIA 42:34-35.

Dragoni, I., C. Balzaretti, S. Rossini, L. Rossi, V. Dell'Orto, and A. Baldi. 2011. Detection of hen lysozyme on proteic profiles of Grana Padano cheese through SELDI-TOF MS high-throughput technology during the ripening process. Food Anal. Methods 4:233-239.

Fratini, F., V. V. Ebani, M. Ampola, E. Innocenti, F. Forzale, M. Periccioli, D. Cerri, and E. Andreani. 2006. Determinazione della concentrazione di lisozima in latte ovino normale e mastitico (Evaluation of lysozyme titration in normal and mastitic ewe milk). Atti XIV Congr. Intern. Fe.Me.S.P.Rum, Lugo, Santiago de Compostela, Spain. Universidade de Santiago de Compostela publicacions.

Frémont, S., G. Kanny, J. P. Nicolas, and D. A. Moneret-Vautrin. 1997. Prevalence of lysozyme sensitization in an egg-allergic population. Allergy 52:224-228.

Galassi, L., E. Salimei, and M. Zanazzi. 2012. Impiego del latte di asina in sostituzione di lisozima da uovo nella produzione del formaggio duro italiano: Prime esperienze (Grana Padano cheese making with lysozyme from ass's milk: first results). J. Ital. Dairy Sci. Assoc. 63:73-79.

Garde, S., R. Arias, P. Gaya, and M. Nunez. 2011. Occurrence of Clostridium spp. in ovine milk and Manchego cheese with late blowing defect: Identification and characterization of isolates. Int. Dairy J. $21: 272-278$.

Guo, H. Y., K. Pang, X. Y. Zhang, L. Zhao, S. W. Chen, and M. L. Don. 2007. Composition, physiochemical properties, nitrogen fraction distribution, and amino acid profile of donkey milk. J. Dairy Sci. 90:1635-1643.

Herrouin, M., D. Mollé, J. Fauquant, F. Ballestra, J. L. Maubois, and J. Léonil. 2000. New genetic variants identified in donkey's milk whey proteins. J. Protein Chem. 19:105-115.

Hughey, V. L., and E. A. Johnson. 1987. Antimicrobial activity of lysozyme against bacteria involved in food spoilage and food-borne disease. Appl. Environ. Microbiol. 53:2165-2170.

Iaconelli, A., L. Fiorentini, S. Bruschi, F. Rossi, G. Mingrone, and G. Piva. 2008. Absence of allergic reactions to egg white lysozyme additive in Grana Padano cheese. J. Am. Coll. Nutr. 27(2):326-331.

ISO. 2000. Whole milk - Determination of milk fat, protein and lactose content. Guide for the operation of mid-infra-red instruments (FIL IDF 141C:2000). International Organization for Standardization, Geneva, Switzerland.

ISO. 2001. Microbiology of food and animal feeding stuffs - Horizontal method for the enumeration of $\beta$-glucoronidase positive Escherichia coli. Part 2: Colony-count technique at $44^{\circ} \mathrm{C}$ using 5-bromo4-chloro-3-indolyl $\beta$-D-glucuronide (ISO 16649-2:2001). International Organization for Standardization, Geneva, Switzerland.

ISO. 2004. Microbiology of food and animal feeding stuffs - Horizontal method for the enumeration of Clostridium - Colony-count technique (ISO 7937:2004). International Organization for Standardization, Geneva, Switzerland.

ISO. 2006a. Milk-Enumeration of somatic cells. Part 2: Guidance on the operation of fluoro-opto-electronic counters (ISO 13366-2|IDF 148-2:2006). International Organization for Standardization, Geneva, Switzerland.

ISO. 2006b. Microbiology of food and animal feeding stuffs-Horizontal method for the enumeration of coliforms - Colony-count technique (ISO 4832:2006). International Organization for Standardization, Geneva, Switzerland.

Kalač, P. 2011. The effect of silage feeding on some sensory and health attributes of cow's milk: A review. Food Chem. 125:307-317.

Kerkaert, B., F. Mestdagh, and B. De Meulenaer. 2010. Detection of hen's egg white lysozyme in food: Comparison between a sensitive HPLC and a commercial ELISA method. Food Chem. 120:580584

La Torre, G. L., M. Saitta, A. G. Potortì, G. Di Bella, and G. Dugo. 2010. High performance liquid chromatography coupled with at- mospheric pressure chemical ionization mass spectrometry for sensitive determination of bioactive amines in donkey milk. J. Chromatogr. A 1217:5215-5224.

Martìnez-Cuesta, M. C., J. Bengoechea, I. Bustos, B. Rodriguez, T. Requena, and C. Pelaez. 2010. Control of late blowing in cheese by adding lacticin 347-producing Lactococcus lactis IFPL 3593 to the starter. Int. Dairy J. 20:18-24.

Nazzaro, F., P. Orlando, F. Fratianni, and R. Coppola. 2010. Isolation of components with antimicrobial property from the donkey milk: A preliminary study. Open Food Sci. J. 4:43-47.

Panari, G., and S. Filippi. 2009. Determinazione del lisozima da bianco d'uovo nel formaggio: Un approccio mediante tecniche di cromatografia a scambio ionico (Detection of hen egg white lysozyme in cheese: an approach using techniques of ion exchange chromatography). J. Ital. Dairy Sci. Assoc. 60:261-265.

Pellegrino, L., and A. Tirelli. 2000. A sensitive method to detect hen egg with lysozyme in milk and dairy products. Int. Dairy J 10:435-442.

Pérez-Calderón, R., M. A. Gonzalo-Garijo, A. Lamilla-Yerga, R. Mangas-Santos, and I. Moreno-Gaston. 2007. Rercurrent angioedema due to lysozyme allergy. J. Investig. Allergol. Clin. Immunol. $17: 264-266$

Polidori, P., and S. Vincenzetti. 2007. Quantificazione del lisozima nel latte di asina in fasi diverse della lattazione (Quantification of lysozyme in donkey's milk at different stages of lactation). Pages 49-51 in Atti II Convegno nazionale sul latte d'asina: Perché, Rome, Italy. Coldiretti, Rome, Italy.

Pulina, G., N. Macciotta, and A. Nudda. 2005. Milk composition and feeding in the Italian dairy sheep. Ital. J. Anim. Sci. 4:5-14.

Scharfen, E. C., D. A. Mills, and E. A. Maga. 2007. Use of human lysozyme transgenic goat milk in cheese making: Effects on lactic acid bacteria performance. J. Dairy Sci. 90:4084-4091.

Schneider, N., C. M. Becker, and M. Pischetsrieder. 2010a. Analysis of lysozyme in cheese by immunocapture mass spectrometry. J. Chromatogr. B Analyt. Technol. Biomed. Life Sci. 878:201-206. (Abstr.)

Schneider, N., I. Weigel, K. Werkmeister, and M. Pischetsrieder. 2010b. Development and validation of an enzyme-linked immunosorbent assay (ELISA) for quantification of lysozyme in cheese. J. Agric. Food Chem. 58:76-81. (Abstr.)

Schneider, N., K. Werkmeister, C. M. Becker, and M. Pischetsrieder. 2011. Prevalence and stability of lysozyme in cheese. Food Chem. 128:145-151.

Senyk, G. F., J. A. Scheib, J. M. Brown, and R. A. Ledford. 1989. Evaluation of methods for determination of spore-formers responsible for the late gas-blowing defect in cheese. J. Dairy Sci. 72:360-366.

Vincenzetti, S., A. Amici, S. Pucciarelli, A. Vita, D. Micozzi, F. M. Carpi, V. Polzonetti, P. Natalini, and P. Polidori. 2012. A proteomic study on donkey milk. Biochem. Analyt. Biochem. 1:109. http://dx.doi.org/10.4172/2161-1009.1000109.

Vissers, M. M. M., F. Driehuis, M. C. Te Giffel, P. De Jong, and J. M. G. Lankveld. 2006. Improving farm management by modeling the contamination of farm tank milk with butyric acid bacteria. J. Dairy Sci. 89:850-858.

Vissers, M. M. M., F. Driehuis, M. C. Te Giffel, P. De Jong, and J. M G. Lankveld. 2007a. Concentrations of butyric acid bacteria spores in silage and relationships with aerobic deterioration. J. Dairy Sci. 90:928-936

Vissers, M. M. M., F. Driehuis, M. C. Te Giffel, P. De Jongvand, and J. M. G. Lankveld. 2007b. Minimizing the level of butyric acid bacteria spores in farm tank milk. J. Dairy Sci. 90:3278-3285.

Wasserfall, F., and M. Teuber. 1979. Action of egg white lysozyme on Clostridium tyrobutyricum. Appl. Environ. Microbiol. 38:197-199.

Zhang, X. Y., L. Zhao, L. Jiang, M. L. Dong, and F. Z. Ren. 2008. The antimicrobial activity of donkey milk and its microflora changes during storage. Food Contr. 19:1191-1195. 